
\title{
Economic and Environmental Analysis of Converting Grid Supplied HPS Lights to solar PV Powered LEDs in Street Lighting at Khairpur Mirs' Pakistan
}

\author{
J. A. Touqeer, H. H. Memon", S. A. Soomro and N. A. Tunio \\ Department of Electrical Engineering, MUET SZAB Campus, Khairpur Mirs'Pakistan; \\ halar.memon@hotmail.com
}

\begin{abstract}
Economic growth is an important factor for the development of any country and mainly it is affected by the energy crises available. Pakistan is among the countries facing the energy threats and shortages. This paper contributes towards reduction of energy crises by moving towards renewable energy resources. The objective of the paper is to utilize the solar energy in replacement of conventional energy resources focusing the street lighting systems. Economic and environmental analysis is made for the replacement of 250W High Pressure Sodium lights with solar powered lights at khairpur Mir's Sindh, Pakistan. For economic analysis, initial cost, energy consumption cost and maintenance cost of both lighting systems are explored while the environmental analysis is carried out by investigating the carbon emission for both of the systems. In addition to this, simple payback period and internal rate of return are also explored for economic analysis. Resultant data obtained from both types of lighting systems is compared with each other to highlight the effectiveness of solar LED lights. Presented analysis shows the attractiveness of solar powered LED lights in the street lighting systems as the government of Pakistan will be saving more than seventy million rupees in 25 years and more than 13 metric tons of carbon emissions are avoided. The results obtained from the study (economic and environment) reflects towards the implementation of such systems utilizing the naturally available resources in the countries like Pakistan. Based on the data, method and results presented such analysis could be done for different areas for different renewable energy sources available in different countries.
\end{abstract}

Keywords: Economic Analysis, Environmental Analysis, HPS lights, Solar Power LEDs, Street Lighting Systems

\section{Introduction}

The economic growth indicators of the Pakistan are getting worst day by day due to energy shortage in country. Presently furnace oil, coal and natural gas are fulfilling the energy needs of the country. A huge percentage of oil is being imported from the oil rich countries due to lack of oil reserves in Pakistan and a huge amount of money are being wasted on oil import. In order to avoid the energy crises and to enhance the economy of the country, the use of oil and gas can be replaced by renewable energy sources especially solar PV technology.

Rapid increment in fuel prices and emission of greenhouse gases since last three decades made renewable energy sources as one of the most economic and reliable sources of energy. Solar energy is one of the major sources of renewable energy which is being widely used all over the world. Fortunately Pakistan is rich in solar energy and it comes in sunny belt of the world due to very high ratio of sunshine day's ratio (i.e., 300+ days per year) and 1900$2200 \mathrm{KWh} / \mathrm{m}^{2}$ average yearly solar insolation ${ }^{1,2}$. Figure 1 provides the data regarding availability of sunlight in Pakistan in form of solar map developed by NREL and USAID The government of Pakistan has set a target of getting at least $5 \%(9700 \mathrm{MW})$ of total power generated from renewable energy resources especially solar PV and solar thermal? 


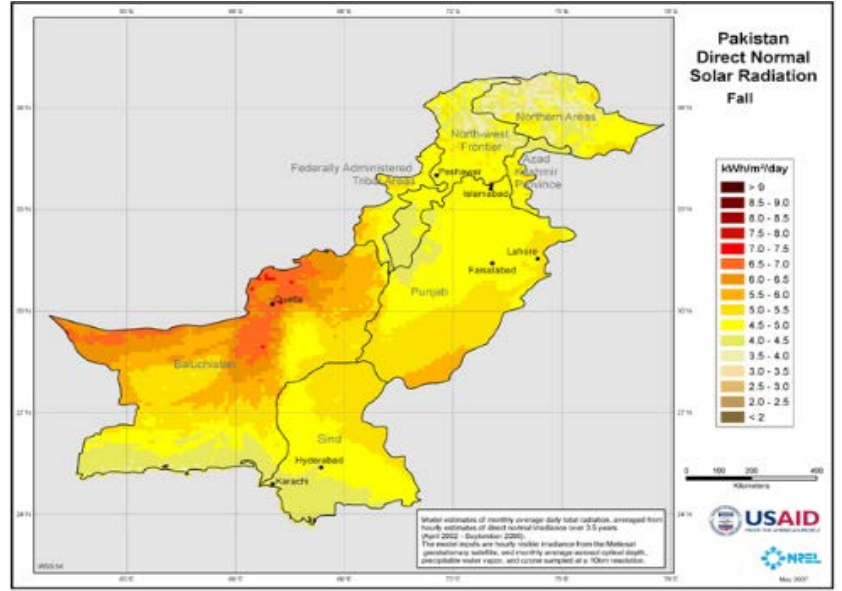

Figure 1. Solar map of Pakistan'

Public lighting in Pakistan consumes about 279Milion $\mathrm{kWh}$ of energy per year which is $0.52 \%$ of its total generation. Keeping in view the current energy crises of the country, two years ago the government has signed an agreement with the Chinese company for replacing old grid powered HPS street lights with solar PV powered LEDs at Khairpur Mirs'. Installation cost of solar PV powered LEDs includes the cost of the LED light, solar panel, pole, battery and solar charge controller. This research work has been carried out with the purpose to find out the attractiveness of the investment on the installation of solar powered auto switching LED lights and its environmental benefits. Furthermore the results of this work will lead to get an insight view on how to lower the current energy crises in the country by using such environmental friendly LED lights.

The flow of research work in the rest of paper is as follows. Section 2 introduces the installed project with technical specifications. Section 3 provides detailed economic analysis starting from its initial capital cost to total cost for both types of lighting systems. It also highlights the attractiveness of the said project by analyzing different economic aspects while Section 4 gives information about environmental effectiveness and finally Section 5 presents some concluding remarks regarding the presented analysis.

\section{LED Lighting Project}

The project of replacing High Pressure Sodium lights (250 $\mathrm{W})$ to solar powered LEDs $(70 \mathrm{~W})$ is almost finished and field operational at khairpur Mirs. Block diagram of the installed project is shown in Figure 2. The installed system consists of a PV module with a solar charge controller to charge the battery during day time so that battery would be responsible to supply the power during night hours via LED driver circuitry. The detailed configuration of installed system is given in Table 1.

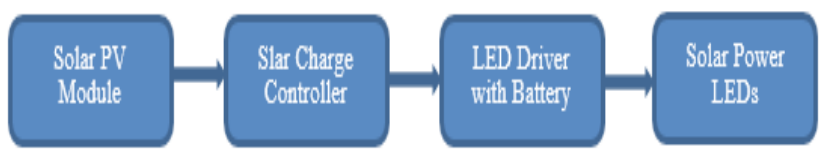

Figure 2. Block diagram of solar power LED street lighting system.

Table 1. LED lighting system configuration for single lighting fixture

\begin{tabular}{ll}
\hline Description & Value \\
\hline Solar Panel & $115 \mathrm{~W} / 18 \mathrm{~V}, 2 \mathrm{PCS}$ \\
LED Lamp & $70 \mathrm{~W} / 24 \mathrm{~V}, 1 \mathrm{PC}$ \\
Battery & 80Ah/12V, 2 PCS \\
Solar Controller & $\begin{array}{l}\text { 10A/24V/12V auto, adjustable working } \\
\text { time \& power }\end{array}$ \\
Pole & $\begin{array}{l}\text { 7.6m height; hot-dip galvanized + plastic } \\
\text { powder coated }\end{array}$ \\
Battery Box & underground waterproof \\
Quantity & 924 Units \\
\hline
\end{tabular}

\section{Economic Analysis}

Economic analysis has been made to economically compare the previous $250 \mathrm{~W}$ HPS lamps with the current solar PV powered $70 \mathrm{~W}$ LED street lights. Different economic assessment measures like annual saving, simple Payback period and Internal Rate of Return (IRR) are explored. The total cost for both the lighting systems is the sum of their initial cost, running cost and the maintenance cost for the prescribed period of time which is 25 years in this case study.

\subsection{Initial capital Cost Analysis}

The capital cost of the project accounts for the cost of purchasing lamp poles, lights, charge controller, batteries, fixative tools and accessories and Government Sales Tax (GST). The prices are referred from the equipment supplier company. Capital cost comparison between HPS lights and Solar PV powered LED lights is presented in Table 2. Cost of one luminaries along with its accessories and cost of transformer is taken from Jinhua Sun-Master solar Technology company Ltd and Pakistan Elektron 
Ltd respectively and the cost of these items was also matching with the current market price at the time of implementation. Based on the cost presented in Table 1, the total initial cost analysis for both types of lightings is shown in Figure 3.

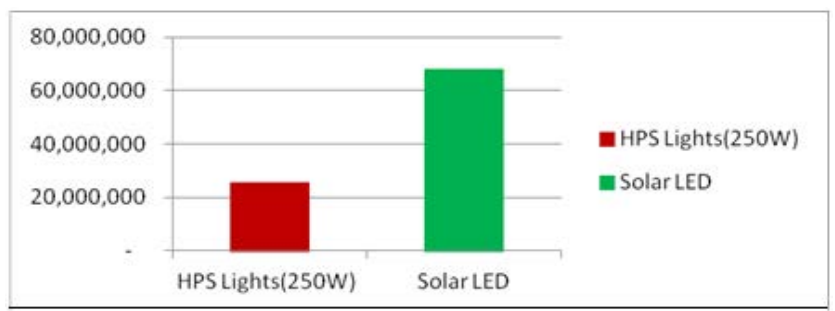

Figure 3. Initial cost comparison.

Table 2. Analysis of capital cost of both type of lighting fixtures

\begin{tabular}{|c|c|c|c|}
\hline Parameter & Unit & $\begin{array}{c}\text { HPS } \\
\text { Lights }\end{array}$ & Solar LED \\
\hline $\begin{array}{l}\text { Cost of one luminaries with } \\
\text { pole }\end{array}$ & PKR & 19,800 & 61200 \\
\hline No. of Luminaries & No. & 924 & 924 \\
\hline cost of 924 luminaries & PKR & 18295200 & 56548800 \\
\hline Transformer capacity required & KVA & 262.5 & - \\
\hline Price for the Transformers & PKR & 1937520 & - \\
\hline GST on imported items & PKR & 3439562 & $9,613,296$ \\
\hline $\begin{array}{l}\text { Miscellaneous cost per } \\
\text { luminaries }\end{array}$ & PKR & 2000 & 2000 \\
\hline $\begin{array}{l}\text { Miscellaneous cost for } 924 \\
\text { luminaries }\end{array}$ & PKR & 1848000 & 1848000 \\
\hline Total initial cost for 924 units & PKR & $25,520,282$ & $68,010,096$ \\
\hline
\end{tabular}

\subsection{Energy Consumption Cost Analysis}

The electricity consumption cost during operation of lamp at night time shares a major portion of cost for any grid powered light. Energy consumption cost for the solar powered auto-switched LED lights is approximated as zero due to the fact that these lights get their power directly from sun and do not get any energy from grid which prevents the overloading condition of transformers for their safe operation. Contrary to solar LEDs lights, the HPS lamps $(250 \mathrm{~W})$ consume a huge amount of energy and become one of the major causes of overloading on existing power systems. Furthermore using auto-switched solar LEDs instead of HPS lamps cause the reduction in line losses and improves the voltage regulation and efficiency of the power system. Table 3 depicts the cost of energy consumption for HPS lights and solar PV powered LED lights for 25 years of operating service and standard value of energy cost of $1 \mathrm{KWh}$ is taken from . Based on the cost presented in Table 3, the total energy consumption cost analysis for both types of lightings is shown in Figure 4. As it is depicted from Figure 4 that energy consumption cost for solar power LEDs is almost zero as compared to HPS lights which consumes considerable amount of energy and hence cost.

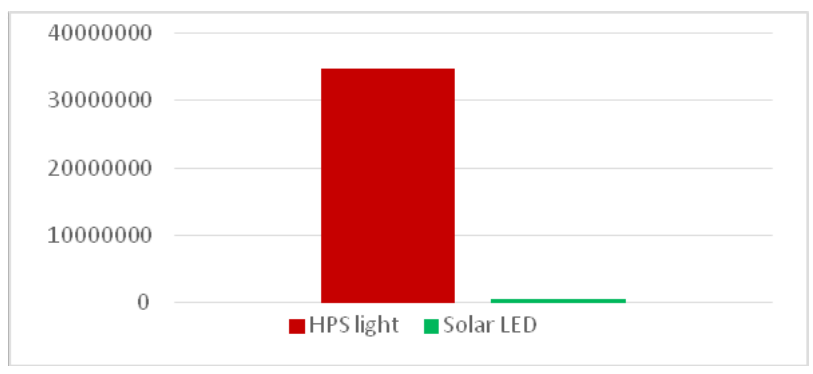

Figure 4. Energy consumption cost comparison.

Table 3. Analysis of energy consumption cost

\begin{tabular}{|c|c|c|c|}
\hline Parameter & Unit & $\begin{array}{c}\text { HPS } \\
\text { Lights }\end{array}$ & $\begin{array}{l}\text { Solar } \\
\text { LEDs }\end{array}$ \\
\hline Rated Watt & Watts & 250 & 70 \\
\hline Power factor & -- & 0.88 & 1 \\
\hline Actual load per lamp & Watts & 284.1 & 70 \\
\hline Daily Usage hours & Hour & 11 & 11 \\
\hline $\begin{array}{l}\text { Daily Energy Consumption for } \\
\text { one unit }\end{array}$ & KWH & 3.125 & 0.7 \\
\hline $\begin{array}{l}\text { Energy Cost for } 1 \mathrm{KWH} \\
\text { consumed }\end{array}$ & PKR & 14 & - \\
\hline Daily Energy consumed Cost & PKR & 43.75 & - \\
\hline Monthly Energy consumed Cost & PKR & 1312.5 & - \\
\hline Year Energy consumed Cost & PKR & 15968.75 & - \\
\hline 25 years Energy cost for 924 units & PKR & 368878125 & - \\
\hline $\begin{array}{l}\text { Fix cost per KW of installed } \\
\text { capacity }\end{array}$ & PKR & 500 & - \\
\hline Total installed capacity & KW & 231 & - \\
\hline $\begin{array}{l}\text { Monthly fixed cost on installed } \\
\text { capacity }\end{array}$ & PKR & 115500 & 0 \\
\hline $\begin{array}{l}\text { Yearly fixed cost on installed } \\
\text { capacity }\end{array}$ & PKR & 1386000 & 0 \\
\hline $\begin{array}{l}25 \text { Years fixed cost on installed } \\
\text { capacity }\end{array}$ & PKR & 34650000 & 0 \\
\hline
\end{tabular}

\subsection{Maintenance Cost Analysis}

Maintenance cost includes the cost of replacing the lamps and related accossries like battery, charge controller, solar plate etc once they complete their life time or before in case of any fault in any device. The maintenance cost comparison for both lighting systems is shown in Table 
4. The data used to calculate the figures given in Table 4 is taken from technical data provided by the supplier company, Jinhua Sun-Master solar Technology company Ltd. It is quite clear from comparison made in Table 4 that solar powered LEDs takes more ammount on its maintenance as compared to the HPS lights and its quite logical as replacing battery, charge controller, LED light and solar panel is more costier than to replace HPS light alone.

Table 4. Analysis of maintenance cost

\begin{tabular}{llcc}
\hline Parameter & Unit & $\begin{array}{c}\text { HPS } \\
\text { Lights }\end{array}$ & Solar LED \\
\hline Average lamp life & Hours & 24,000 & 50,000 \\
$\begin{array}{l}\text { Hours of operation/day } \\
\text { Hours of operation/ year }\end{array}$ & Hours & 4,015 & 11 \\
$\begin{array}{l}\text { Cost to replace the 924 } \\
\text { lamps once }\end{array}$ & PKR & $6,468,000$ & $42,688,800$ \\
$\begin{array}{l}\text { Cost to replace the 924 } \\
\text { lamps for 25 years }\end{array}$ & PKR & $31,649,743$ & $117,945,828$ \\
\hline
\end{tabular}

The solar pannels and poles do not need any replacement in 25 years so their cost of replacement is approximated as zero. Pictorial analysis for the maintenance cost for both lightings is shown in Figure 5. Solar LED lights inspite of owing very high initial and replacement cost, yet they are better from economical point of view than grid powered HPS lights because of their nonreliabilty on grid power.

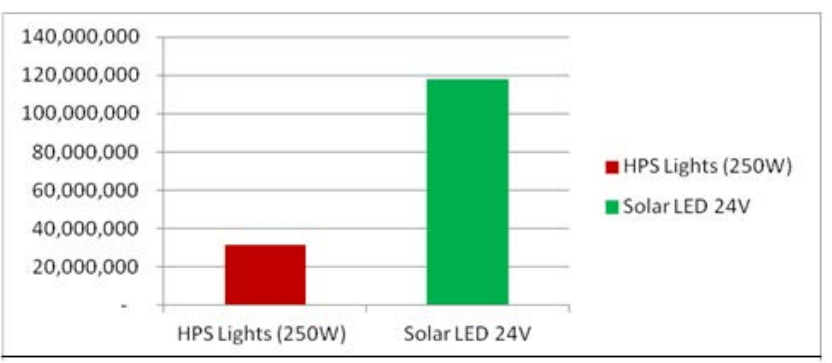

Figure 5. Maintenance cost comparison.

Solar power LED lights are better economical choice than their counterpart conventional lights in spite of having high initial capital and relamping cost. This is because of their capability of saving the energy and providing uninterruptable glow throughout the night.

\subsection{Total Cost and Saving}

Adding all the above mentioned costs individually for the complete project would give total cost of each lighting system. Therefore, the total cost can be calculated by the equation:

$\mathrm{C}_{\mathrm{T}}=\mathrm{Cc}+\mathrm{C}_{\mathrm{EC}}+\mathrm{C}_{\mathrm{R}}$

where $\mathrm{C}_{\mathrm{T}}$ is the total cost, $\mathrm{Cc}$ is capital cost, $\mathrm{C}_{\mathrm{EC}}$ is energy consumption cost and $C_{R}$ is replacement cost of both HPS and Solar power LEDs. Based on the facts and figures of these three individual costs, the total cost is presented in Table 5.

Table 5. Analysis of saving and total cost for both type of lightings

\begin{tabular}{lccc}
\hline Parameter & Unit & HPS Lights & Solar LED \\
\hline Total cost for 25 Years of & PKR & $460,698,151$ & $185,955,924$ \\
operation & & & \\
Saving in 25 years life span & PKR & $274,742,227$ \\
Saving /year & PKR & $10,989,689$ \\
\hline
\end{tabular}

Saving is obtained by using equation:

Saving $=\mathrm{T}_{\mathrm{CH}}-\mathrm{T}_{\mathrm{CL}}$

where $\mathrm{T}_{\mathrm{CH}}$ is the total cost of HPS lighting and $\mathrm{T}_{\mathrm{CL}}$ is the total cost for LED lights. The net saving is obtained by taking the difference in Equation (2) for 25 years of operation as shown in Table 5.

\subsection{Annual Cash Flow and Simple Pay-Back Period}

The cost of Installation of single solar PV powered LED light and GST imposed on it has been calculated as 73,604 PKR. Thus for 924 units of same light the cost will be 68,010,096 PKR. Therefore, replacing HPS luminaires with solar powered LEDs would result in saving of $10,989,689$ PKR per year. Figure 6 shows the 25 years cash flow graph of the investment.

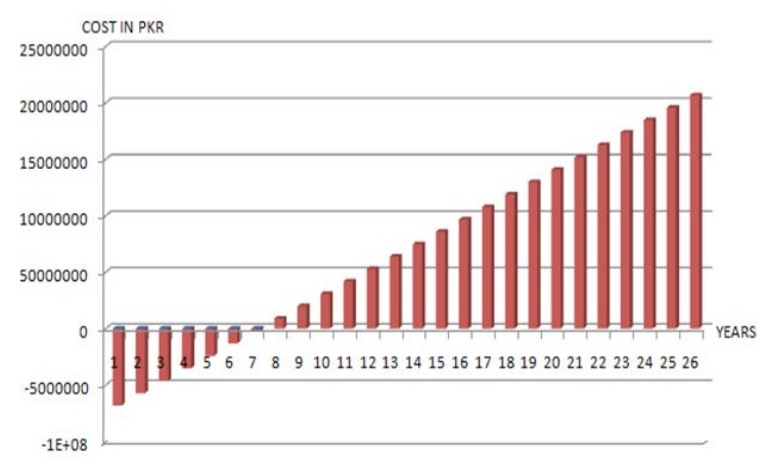

Figure 6. Simple cash flow for investment for 25 years. 
In Figure 6, the negative value of cash represents the investment and the positive value represents saving. The time where the saving equalizes the capital cost for the same investment is the simple pay-back period. It is obtained as :

$\mathrm{P}_{\mathrm{P}}=\mathrm{C}_{\mathrm{I}} / \mathrm{A}_{\mathrm{CF}}$

Where $P_{P}$ is the pay-back period, $C_{I}$ is the capital investment and $\mathrm{A}_{\mathrm{CF}}$ is the annual cash flow. The simple pay-back period is 6.19 years in this case based on the data of $\mathrm{C}_{\mathrm{I}}$ and $\mathrm{A}_{\mathrm{CF}}$ from Table 2 and Table 5 respectively. This pay-back period is also justified from Figure 6 and it shows the time for recovery of initial capital cost.

\subsection{Annual Cash Flow based on Net Present Value}

It is well known fact that due to inflation the value of cash decreases with time. In order to accommodate this decrement in cash value so as to calculate the saving for the said period, the net saving based on Net Present Value (NPV) of cash is calculated and it is obtained by using the following equation肘

$\mathrm{P}_{\mathrm{V}}=\mathrm{F}_{\mathrm{V}} /\left(1+\mathrm{I}_{\mathrm{I}}\right)^{\mathrm{n}}$

Where $\mathrm{P}_{\mathrm{v}}$ is the present value, $\mathrm{F}_{\mathrm{v}}$ is the future value of cash, $I_{I}$ is the interest rate on investment and $n$ is the number of periods normally taken in years. In this analysis, rate of interest is taken $6 \%$. Figure 7 shows the cash flow for the investment with $6 \%$ rate of interest.

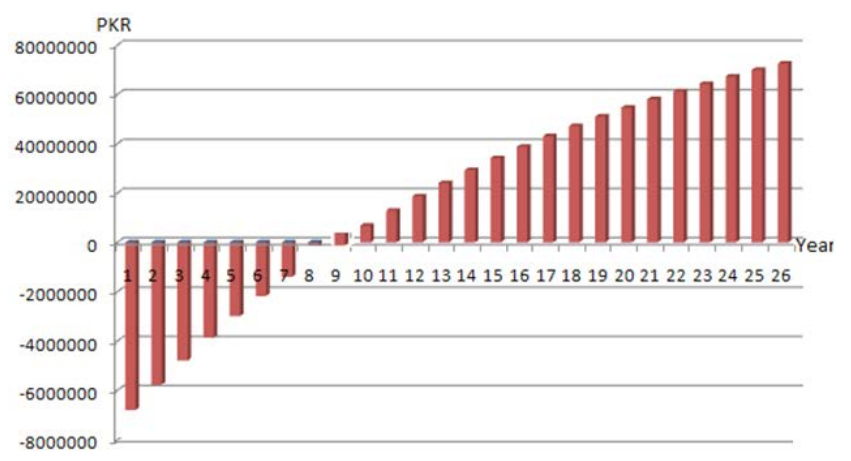

Figure 7. 25 years Cash flow for investment based on net present value method.

Based on the data, it is calculated that net saving per annum is 5,619,404 PKR and net saving for period of 25 years is $72,475,013$ PKR after replacing the 924 units of HPS 250W street lights with 70W solar powered LED lights. Pay-back period for the cash flow based on present value method is calculated by using following equation:

$\mathrm{P}_{\mathrm{P}}=\mathrm{Y}_{\mathrm{LC}}+\left(\mathrm{Y}_{\mathrm{NP}} / \mathrm{S}_{\mathrm{YN}}\right)$

where $\mathrm{P}_{\mathrm{P}}$ is the pay-back period, $\mathrm{Y}_{\mathrm{LC}}$ is the year with last negative value of cash, $\mathrm{Y}_{\mathrm{NP}}$ is the last year of cash flow with negative present value and $\mathrm{S}_{\mathrm{YN}}$ is the present value of saving for the next year. Therefore, the pay-back period based on present value method is 7.97 years and it is interpreted as the initial capital cost paid for installing 924 units of solar LED lights will be recovered in this period of time and it is also obvious in the Figure 7.

\subsection{Internal Rate of Return}

Internal Rate of Return (IRR) provides the information regarding the investment that causes NPV of all future cash flows to be zerof. IRR is a significant tool to measure the desirability and attractiveness of an investment. When the value of IRR is more as compared to the discount factor then the positive value of saving is obtained and the investment would be useful but if reciprocal is true then investment would be useless?

The value of IRR for the investment of this project is obtained as $15.74 \%$ which is greater than the discount factor of $6 \%$ and it is concluded that investment for the replacement of solar powered LED lighting system project is attractive and useful.

\section{Environmental Analysis}

In parallel with economic analysis, environmental effects are also considered while implementing such type of projects. When environmental effects are considered, generally emissions of carbon dioxide are under observation. For a combined cycle power plant, emission of carbon dioxide on average is $570 \mathrm{~g} / \mathrm{kWh}$ for power generation services over worldwide ${ }^{\text {to }}$. As for as environmental effects are concerned, it is fruitful to encounter the effect of $\mathrm{CO}_{2}$ emissions for HPS lights. For a single HPS lamp of 250W, energy consumption in $\mathrm{kW}$ per day is $2.75 \mathrm{kWh}$ for 11 hour of operational time. Therefore, energy consumption for a month and a year would be $82.5 \mathrm{kWh}$ and $990 \mathrm{kWh}$ respectively. Carbon dioxide emissions for dual cycle power plant are calculated as 
$\mathrm{E}_{\mathrm{CO}}=\mathrm{E}_{\mathrm{CY}}{ }^{\star} 0.570 \mathrm{~kg} / \mathrm{kWh}$

where $\mathrm{E}_{\mathrm{CO}}$ is the $\mathrm{CO}_{2}$ emissions per year and $\mathrm{E}_{\mathrm{CY}}$ is energy consumption per year. By using Equation (6), $\mathrm{CO}_{2}$ emissions per year for one unit and 924 units of $250 \mathrm{~W}$ HPS lights are calculated as $564.3 \mathrm{~kg}$ and 14.11 Metric tons respectively. Similarly, for 924 similar units in 25 years will emit 13,035.33 metric tons of $\mathrm{CO}_{2}$ emissions. As these HPS lights are replaced with solar power based LEDs, the $\mathrm{CO}_{2}$ emissions are almost negligible for replaced lights which are favorable from environmental hazards point of view.

\section{Conclusion}

A detailed economic and environmental analysis for the project of replacement of grid supply based HPS lights with solar power based LED lights in street lighting system at khairpur Mirs' Pakistan is presented in this paper. Presented analysis indicated that government will save about 72,475,013 PKR and will reduce carbon emission around 13,035.33 metric tons in the prescribed period of 25 years. The calculated pay-back period of this project is 7 years and 11 months, reflects the attractiveness towards the implementation of solar powered LED lighting systems. The benefits and paybacks, as outlined in the text, LED lights powered by PV modules is the effective solution as it is economically feasible and environmental affability.

\section{Acknowledgement}

All praise to ALLAH, the Almighty, the most merciful and compassionate, who granted us perseverance to accomplish this research work.

\section{References}

1. Shaikh PH, Shaikh F, Mirani M. Solar energy: Topographical asset for Pakistan. Appl Sol Energy. 2013; 49(1):49-53.

2. Malik SR, Maqbool A, Khan JR. Energy Potential of Pakistan. International Conference on Energy and Advancements in Process Engineering (ICEAPE); Faisalabad, Pakistan. 2010 Dec 28-29.

3. NREL, Solar map of Pakistan. US National Renewable Energy Laboratory.

4. Government of Pakistan. Energy. Pakistan Economic Survey, 2013-2014.

5. National Electric Power Regulatory Authority Pakistan Tarrif; 2015.

6. Kumar KA, Sundareswaran K, Venkateswaran PR, Palani S, Naina BR. Design, implementation and economic analysis of sustainable LED roadway lighting system in industrial environment. International Conference on Industrial Instrumentation and Control (ICIC); Pune. 2015. p. 77-82.

7. Mehmood A, Shaikh FA, Waqas A. Modeling of the solar photovoltaic systems to fulfill the energy demand of the domestic sector of Pakistan using RETSCREEN software. International Conference and Utility Exhibition on Green Energy for Sustainable Development (ICUE); Pattaya. 2014. p. $1-7$.

8. Pakistan SB. Monitory Policy Statement.

9. Brealey RA, Myers SC. Principles of corporate finance. 6th ed. Irwin: McGraw-Hill; 2008.

10. Mletzko J, Ehlers S, Kather A. Comparison of natural gas combined cycle power plants with post combustion and oxyfuel technology at different $\mathrm{CO} 2$ capture rates. Energy Procedia. 2016; 86:2-11. 